QL

511

B3

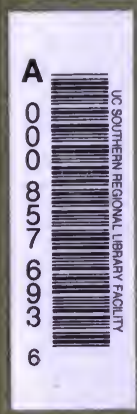

tin of the Museum of Comparative Zoölogy

AT HARVARD COLLEGE.

Vol. LXII. No. 1.

NEW NEUROPTEROID INSECTS.

By Nathan Banks.

Wrth Two Plates.

CAMBRIDGE, MASS., U. S. A.

PRINTED FOR THE MUSEUM.

MARCH, 1918. 
滔 


Bulletin of the Museum of Comparative Zoölogy

AT HARVARD COLLEGE.

VoL. LXII. No. 1.

NEW NEUROPTEROID INSECTS.

By Nathan Banks.

$==$

With Two Plates.

CAMBRIDGE, MASS., U. S. A.

PRINTED FOR THE MUSEUM.

MARCH, 1918. 


$$
\begin{aligned}
& Q L \\
& 511 \\
& 33
\end{aligned}
$$

DILEARY

HRVINA 


\section{No. 1.- New Neuropteroid Insects.}

\section{By Nathan Banks.}

$\mathrm{ON}_{\mathrm{N}}$ the following pages are brought together descriptions of various new species, partly from the United States, partly from foreign countries. Except in the few particularly designated, the types are in the collection of the Museum of Comparative Zoölogy, (Nathan Banks Coll.).

\section{Psocidae.}

Psocus Longipennis, sp. nov.

Type-- M. C. Z. 10,038. Colo.: Boulder, 30 August. T. D. A. Cockerell. One specimen.

Head brown, shining, a pale spot each side above near eye; antennae dark, not very long-haired; thorax black, shining; abdomen brown; legs pale brownish; wings hyaline; venation dark, stigmal vein brown, stigma a uniform pale brown, very long and slender and broadly rounded behind; discal cell four-sided, basal side convex basally, outer side straight, about twice as broad above as behind, the usual parts of venation hyaline; the radial sector from discal cell to the forking is more strongly curved toward the stigma than in most species.

Length $7 \mathrm{~mm}$. Distinct by very long wings.

Psocus ADditus, sp. nov.

Type.- M. C. Z. 10,039. N. Y.: Sport Island, Sacandaga River, 27 June, C. P. Alexander; Md.: Beltsville, 9 June. N. Banks. Two specimens.

Black, head rather dull, legs brown, venation black, the usual pale spaces, and besides the radial sector just beyond the connection to median vein is plainly hyaline for some distance (not noticed in any other species); a black, irregular band before middle of wing, ending on the end of anal vein; the outer two thirds of the stigma dark, a faint cloud behind the forking of the radial sector (as in P. striatus); stigmal vein pale on basal part; stigma moderately long, nearly 
angulate behind; discal cell long, four-sided, not much wider at base than at tip; antennae short, pilose.

Length $4 \mathrm{~mm}$.

Psocus petiolatus, sp. nov.

Type-- M. C. Z. 10,040. Va.: Falls Church, 30 June. N. Banks. Two specimens.

Yellowish, nasus faintly brown, lineate, palpi pale, antennae blackish; thorax black above, sutures pale; abdomen brownish; legs yellowish. Wings hyaline, an indistinct band before middle, ending on end of anal vein, stigma dark in the outer two thirds; venation mostly dark, the usual hyaline spaces; stigma rather abruptly angulate behind; discal cell four-sided, short petiolate from the radius, outer side straight, inner side convex toward base; antennae with only very short hair.

Length $3.5 \mathrm{~mm}$.

Closely related to $P$. bisignatus, differs in shape of discal cell, larger size, less distinct band on wing, absence of dark behind stigma, and paler nasus.

Psocus bilobatus, sp. nov.

Type-M. C. Z. 10,041. Maine: Ft. Kent, 14 August. C. W. Johnson. One specimen.

Coloration similar to $P$. purus; wings longer than $P$. purus, the stigma very much more elongate and slightly rounded behind, a little darker than rest of wing, and containing a small, faint, dark cloud, discal cell with a small dark spot over basal angle, the outer side strongly concave outwardly, so that the cell is five-sided; stigmal vein nearly unicolorous, but rather pale; antennae very long-haired as in $P$. purus; tip of male abdomen very strongly bilobed (Plate 1, fig. 1). Length $6 \mathrm{~mm}$.

Differs from $P$. purus by longer stigma, unicolorous stigmal vein, spot at base of discal cell, and male genitalia.

Amphigerontia formosa, sp. nov.

Type.-M. C. Z. 10,042. Queensland: Kuranda. R. C. L. Perkins. One specimen.

Dull yellowish; clypeus in the middle and the nasus brownish, last joint of palpi black; antennae with basal joints and the first long 
joint yellowish, rest black; three large, shining black spots occupy most of mesonotum; abdomen blackish; legs pale, tips of tibiae and the tarsi blackish. Wings hyaline; veins reddish brown, lower side of radial fork (except near tip), the outer side of discal cell, connecting vein to hind margin, and the anal (except tip) whitish. Stigma moderately long, almost angulate behind; tip of wing almost acute; stigma dark brown, a large apical brown cloud from below stigma out between radius and median and over all the last and most of adjoining posterior cell; a cloud along the subcosta; a large one basad of the discal cell. Hind wings hyaline, basal part rather dusky behind, veins brownish; venation (Plate 2, fig. 24).

Length to tip of wing $7 \mathrm{~mm}$.

\section{Hemipsocus selysi, sp. nov.}

Type-M. C. Z. 10,043. Mid Queensland. R. C. L. Perkins. One specimen.

Pale yellowish. Head broad, vertex rather flat, eyes small, a red line below and one above each antenna horizontally back to the eye, vertex with a red line near each eye, curved in front, divergent lines back from ocelli, and a reddish patch each side; in front of the ocelli are several faint, short, reddish lines. Legs wholly pale, antennae pale, the joints beyond middle rather darkened at base. Wings smoky, darkest near the veins which thus appear margined, these veins broad and pale, the apical ones with some blackish dots and ending in larger black dots; the anal vein, however, is fine and dark colored. Venation (Plate 2, fig. 19).

Length to tip of wing $4 \mathrm{~mm}$.

Taeniostigma Perkinsi, sp. nov.

Type--M. C. Z. 10,044. Mid Queensland. R. C. L. Perkins. One specimen.

Dull yellowish, nasus very much swollen; the antennae pale on the basal part, apical third or half of third and following joints black, the basal third of the fourth and following joints snow-white, tips of tibiae and last joint of tarsi black. Wings hyaline, venation yellowish, no marks, stigma scarcely darker than elsewhere. Wings long, nearly acute at tip; stigma very slender, but tapering to each end; venation (Plate 2, fig. 23).

Length to tip of wing $6.5 \mathrm{~mm}$. 


\section{Perlidae.}

Perla innota, sp. nov.

Type.-M. C. Z. 10,045 . N. Y.: Ithaca, 8 July. N. Banks. One specimen.

Face marks and antennae like $P$. illustris, also the thorax and legs marked about the same; the abdomen above is nearly wholly yellow, the last segment is darker, but with pale apical margin except a median deep black spot; setae black. Wings hardly discolored; venation quite dark, except costal cross-veins. Anastomosis disjointed, the radial sector beyond is twice forked; about five median and eight cubital cross-veins; branches of anal cell wide apart at base. Related to $P$. illustris, but the female ventral plate (Plate 2, fig. 18) is more pointed, with a notched tip, and convex sides, and shows two dark spots.

Expanse $44 \mathrm{~mm}$.

\section{Perla titusi, sp. nov.}

Type--M. C. Z. 10,046. Idaho: Blackfoot, 22 June. E. G. Titus. One specimen.

Brown; yellow median spot on vertex, connected to median stripe over pronotum, setae yellow at base; antennae brown, palpi dark brown; legs yellow-brown, tarsi darker. Ocelli form a triangle more than twice as broad as long, lateral ocelli much nearer eyes than to each other; lateral bosses small, transverse, nearer to lateral ocelli than to the eyes. Pronotum not one fourth broader than long, sides parallel, angles square, moderately rugose above. Wings lightly infumate, venation yellowish brown; radial sector three-branched beyond anastomosis, the latter continuous, not disjointed; three or four cross-veins beyond end of the subcosta, about eight before, about eight median and cubital cross-veins; radial sector geniculate at origin, branches of anal only slightly curved, and as far apart at base as one half length of outer side of anal cell; outer part of cubitus gives off two branches. Ventral plate (Plate 2, fig. 25).

Expanse $35 \mathrm{~mm}$.

\section{Alloperla infirma, sp. nov.}

Type.-M. C. Z. 10,047. Colo.: North Boulder Creek, 22 August; Florissant, 30 August. S. A. Rohwer; Grant, 20 August. E. C. Jackson. Seven specimens. 
Pale yellowish (greenish in life), eyes and ocelli black, pronotum rather fumose, the margin black all around except in the middle behind; hind margin of meso- and of metascutellum black; tarsal claws' black; venation pale. Ocelli forming a triangle a little broader behind, posterior ocelli plainly nearer to eyes than to each other; pronotum two and a half times as broad as long, sides evenly rounded, surface faintly rugulose; legs slender, tibia I as long as width of the pronotum. Wings moderately long, radial sector one-branched beyond anastomosis, the fork with a long pedicel; about four mediocubital cross-veins; anastomosis widely disjointed; cubital sector soon runs into hind margin.

Expanse $16 \mathrm{~mm}$.

Alloperla lineosa, sp. nov.

Type-- M. C. Z. 10,048. Colo.: Grant, 20 August. E. C. Jackson. Two specimens.

Pale yellowish (green in life), eyes and ocelli black; pronotum with a median black line which is enlarged at each end, and continued back over the middle of the thorax and most of the abdomen; venation pale. Ocelli in an equilateral triangle, posterior ocelli no nearer to eyes than to each other; pronotum twice as broad as long, sides rounded, surface finely rugulose; legs slender, tibia I longer than width of the pronotum. Wings of moderate length, anastomosis widely disjointed, radial sector one-branched beyond, the pedicel long; about three medio-cubital cross-veins; cubital fork soon runs into the margin.

Expanse $14 \mathrm{~mm}$.

Taeniopteryx parvula, sp. nov.

Type-- M. C. Z. 10,049. Va.: Peach Grove Hill, February; D. C.: Washington, February. N. Banks. Two specimens.

Black; head and thorax densely clothed with minute gray pubescence; legs more brownish. Ocellar triangle fully twice as broad as long, the lateral ocelli only little more than their diameter from the eyes. Pronotum one and two thirds as broad as long, as broad in front as behind, sides parallel; hind tibia of male slightly sinuate. Wings gray fumose, rather darker in stigmal region; no pale band. Costal area with only basal cross-vein; no cross-vein beyond end of subcosta; radial sector with one branch, this just beyond the cross- 
vein, the anastomosis is continuous and not disjointed, the connection from radial sector to median being nearly straight across (not oblique). Venter (Plate 1, fig. 2). Male genitalia (Plate 1, fig. 3).

Expanse $17 \mathrm{~mm}$.

Taeniopteryx grinnelli, sp. nov.

Type.- M. C. Z. 10,050. Calif.: Millard Canon, Pasadena, 10 April. F. Grinnell. Two specimens.

Dull dark brown or blackish; legs and antennae paler yellowish brown, tips of femora, bases and tips of tibiae, and the tarsi darker; male genitalia yellowish. Ocelli form a triangle a little broader than long, the hind ocelli almost twice their diameter from the eyes; pronotum one and a third times as broad as long, broadest just before the middle the sides convex, a few, rather large smooth, raised spots on the disc behind the transverse furrow. Fore wings with a pale band across just beyond the end of the subcosta; the radial sector with but one branch, this shortly beyond the cross-vein; the costal area has the usual basal cross-vein, but no other cross-veins till near the tip. Male hind femora unarmed, and the tibia straight. Male genitalia (Plate 1, fig. 6).

Expanse $20 \mathrm{~mm}$.

Taeniopteryx (Rhabdiopteryx) NigRipennis, sp. nov.

Type--M. C. Z. 10,051. Wash.: Wenatchee, 31 May. E. J. Newcomer. Three specimens.

Black, with black wings. Head a little paler near the mouth, tips of tibiae (in o ) pale; basal costal part of wings pale, and with partly yellowish venation; wings darkest in apical costal part, and near the anastomosis; venter pale, in $\sigma^{7}$ the apical plate is pale yellowish with a black superior margin. Costal area with a basal cross-vein, and usually two toward the end of the subcosta, radial sector with one fork, likewise the median and cubital veins end in one fork, the latter hardly more basad than the former; five to six median cross-veins, six to eight cubital cross-veins; the posterior ocelli hardly more than twice as far from each other as from the eyes; pronotum one and a third times as broad as long, sides convex, anterior corners rounded, rather numerous rugosities each side; ventral plate of the $q$ rather broad, broadly rounded at tip. The apical plate of $\sigma^{\pi}$ is long and tapering. Venter ơ $\&$ (Plate 1, fig. 4).

Length $20 \mathrm{~mm}$. 


\section{Taeniopteryx (Rhabdiopteryx) pallida, sp. nov.}

Type.-M. C. Z. 10,052. Wash.: Wenatchee, 31 May. E. J. Newcomer, Three specimens.

More or less reddish, legs and wings pale. Head dull reddish, paler around mouth, a large black patch above antennae to the posterior ocelli, and behind on vertex blackish, antennae black, palpi pale, pronotum dull blackish in middle, reddish on front, behind, and on sides, rest of thorax and the abdomen blackish, apical part of venter and the ventral plate of female pale. Legs pale, tarsi darker, and femora sometimes infuscate above. Wings grayish hyaline; costa, subcosta, and radius pale, except near tip, other veins brown to black, end of radius rather broadly blackish, a basal costal cross-vein and one or two toward end of the subcosta; about six cross-veins in median and in cubital areas, median and cubitus end in one fork, that of the latter some distance before the former; radial sector with one branch at or just beyond the anastomosis; the female ventral plate (Plate 1, fig. 7) rather long, broadly rounded at the tip. The posterior ocelli more than twice as far apart as from the eyes. Pronotum nearly one and a half times as broad as long, sides slightly convex, anterior corners rounded, surface with but few rugosities each side.

Expanse $19 \mathrm{~mm}$.

\section{ARSAPINA BaKeri, sp. nov.}

Type--M. C. Z. 10,053. Calif.: mountains near Claremont. C. F. Baker. One specimen.

Black; legs, antennae, and setae yellowish brown, tarsi darker. Head and ocelli similar to $A$. decepta, but a large triangular boss obliquely in front of each lateral ocellus. Pronotum only a little broader than long; sides rather convex; setae fully as long as abdomen, the joints elongate. Wings dark gray, darker along stigmal area and along outer hind margin; pale areas above and behind the anastomosis; cross-vein beyond end of subcosta arises just above the anastomosis, the radial sector at anastomosis almost forks; that is the posterior section of anastomosis is very short; and this branch is very concave near base. The cubital vein has a distinct apical fork. (Plate 2, fig. 26).

Expanse $17 \mathrm{~mm}$. 


\section{EPHEMERIDAE.}

Euthyplocia intercalata, sp. nov.

Type-- M. C. Z. 10,054. E. Colombia: Mediao. A. H. Fassl; British Guiana: Bartica. H. E. Parish; Guyane Française. E. Le Moult. Four specimens.

우 Resembles $E$. hecuba, about as large, and colored about the same; the costal area toward base is rather darker than in $E$. hecuba. Dorsal abdominal segments pale, with the posterior margin of each darker. It is separated at once from $E$. hecuba by the presence of five pairs of long intercalaries in each fore wing; one pair between lower branch of vein 7 and vein 8 , one pair between upper and lower branches of vein 7 , one between veins 6 and 7 , one between upper branches of vein 6 , and one between vein 5 and lower branch of vein 4 . Vein 8 has a long branch parallel to it (as in E. anceps).

Expanse $50 \mathrm{~mm}$.

\section{Campsurus parishi, sp. nov.}

Type--M. C. Z. 10,055. Ecuador: Durar, 21 June. H. S. Parish. Four specimens.

$\sigma^{\top}$ Body pale; head blackish between eyes, dark on metanotum, and at tip of abdomen; legs of front pair blackish, their claws white, and nearly as long as last tarsal joint; setae wholly pale. Costal veins heavier and grayer than others so that the costal area appears darkened, rest of wing whitish hyaline with white venation. Vein 8 has one branch which soon forks, but few if any cross-veins between these forks nor to the hind margin of wing. The male genitalia (Plate 1, fig. 5) shows the middle pair of appendages very long, more than half as long as the lateral ones.

Expanse $24 \mathrm{~mm}$.

Thraulus trijuncta, sp. nov.

Typc--M. C. Z. 10,056. Peru: Lima, 21 August. H. S. Parish. Two specimens.

Head black between eyes; thorax brown, sutures and ridges on sides white; pronotum white on sides; tip of scutellum pale, basal abdominal segment dark brown, next five segments very pale, each with a dark dot each side, seventh segment dark brown in middle, 
pale each end and on the sides, eighth with median dark line and basal band, ninth rather darker with dark median stripe, tenth dark except apical and lateral margin; setae pale, every fourth segment wholly dark, the joinings between dark (Plate 2, fig. 20); all femora with a rather broad preapical band, femur I of male with subbasal band also, and the tip of tibia dark. Wings hyaline; veins mostly yellowish or pale brown, great cross-vein broadly black, no cross-veins in basal costal area, 10 or 12 in apical part, most of the cells of wing twice as long as broad, no true intercalaries.

Expanse $16 \mathrm{~mm}$.

Callibaetis nigrivenosa, sp. nov.

Type.-M. C. Z. 10,057. Ecuador: Huigar, 4,500 ft., 17 June. H. S. Parish. One specimen.

Rich dark brown; abdomen near tip with pale on sides of segments; legs pale. Wings with a faint dark tinge, very deep and prominent on apical costal area; all veins very dark brown or nearly black; margin with two moderately long intercalaries in each space; about 10 or 12 cross-veins in costal area; two series of discal cross-veins, about 5 or 6 in the inner series, about 15 in outer series, but none of these anywhere near margin, many as near to inner series as to margin.

Expanse $24 \mathrm{~mm}$.

\section{Callibaetis signata, sp. nov.}

Type.-M. C. Z. 10,058. Ariz.: Williams, 24 July. H. S. Barber. Two specimens.

ㅇ Pale brownish; scutellum pale in middle; abdomen dotted; setae pale, with the joinings dark; legs pale, tarsi and tibiae at tips rather darker. Wings hyaline, longitudinal veins brown, cross-veins hyaline, none near the hind margin; various pale brown spots along costal region but not forming a continuous stripe; several costal dots, a basal streak, one just before middle of wing on subcosta and radius, and three or four beyond, several other brown spots.

$\sigma^{7}$ Rather darker brown, the abdomen shows above two large pale spots, one over the penultimate segment, and the other on the third segment before the last, between these spots the dorsum is nearly black; venter finely dotted. Wings hyaline, no spots, longitudinal veins brown, others hyaline.

Expanse $15 \mathrm{~mm}$. 
Callibaetis nigrita, sp. nov.

Type--M. C. Z. 10,059. Cölo.: Boulder, May. T. D. A. Cockerell. One specimen.

$\sigma^{T}$ Dark brown; back of thorax blackish; abdomen dotted, the dorsum with a median darker stripe, on the last few segments this darker stripe is pale in the middle; venter with a pair of dark submedian stripes on each segment; front legs very dark, others pale, femora before tip and the tarsi darker; male genitalia and the setae pale yellowish. Wings hyaline, veins white, the longitudinal ones with some black streaks, hind margin alternately dark and pale; many cross-veins, a number near the hind margin. The male with costal area marked with black (not brown) spots, but not forming a continuous streak; various dots along costal margin, streaks along veins, and larger spots beyond the middle, two being larger than others.

Expanse $20 \mathrm{~mm}$.

\section{Hemerobitdae.}

Nosybus navasi, sp. nov.

Type.-British Museum. Africa: Gold Coast, Aburi. Patterson coll.

Face yellowish, clypeus brownish, vertex with tufts of long white hairs, also on the pronotum; antennae as long as width of fore wings, curled, tapering to tip, rich brown in color. Abdomen brown, with median lobes above, with sparse white hair above and denser yellowish hair on sides; the ovipositor yellowish, about one third the length of the abdomen; legs pale, tarsi yellowish, basal half of hind tibia and apical part of middle tibia dark, legs with mostly long white hairs, but some dark ones. Fore wing with two faint broad oblique gray bands, one before middle, one at the middle, and several large patches beyond, the space between these marks snow-white; the cross-veins black, and black haired, and a black spot at anal angle, other veins mostly yellowish, with long hairs, mostly white, but some in costal area are black. Venation very similar to $N$. nobilis Navas, but a cross-vein connecting the second and third branches of the radial sector toward tip, thus four veinlets in the outer series of gradates; hind wings similar to $N$. nobilis, but no cloud back of the stigma, the latter very distinct. Veins similar to $N$. nobilis, but the extra apical cross-vein, the lack of cloud in hind wings, several details in color of 
legs, as well as different locality lead me to consider it a distinct species.

Expanse $15 \mathrm{~mm}$.

Navas has placed this genus in the Hemerobiinae, but its extreme likeness to Dilar, leads me to think it is very near that genus and that the male will have pectinate antennae. It has no close affinity to Neurothus, except the one radial sector, a character of no great value, and liable to variation in the Hemerobiidae.

\section{Notiobiella costalis, sp. nov.}

Type.-British Museum. Africa: Gold Coast, Aburi. Patterson coll.

Pale greenish yellow (doubtless green in life); veins green, practically all the forkings (except the marginal ones) clouded, the crossveins margined, and several other clouds in the cells, one series forming a faint band some distance before the tip; hind wings unmarked. Fore wings about two and a fourth times as long as broad, the costal area extremely broad; at origin of the first radial sector the costal area is nearly as broad as the rest of the wing at that place, the middle series of cross-veins not very oblique, and disjointed. In hind wings the radial sector forks twice before the stigma.

Expanse $11 \mathrm{~mm}$.

Its broad costal area and shape of superior appendages of the male (Plate 2, fig. 21) separate it from the other described African species of the genus.

\section{Chrysopidae.}

LEUCOCHRYSA CLYSTERA, sp. nov.

Type.-M. C. Z. 10,060. Colombia: San Antonio, 6,000 ft., February. A. H. Fassl. One specimen.

Runs to $L$. montanola or neuralis in Navas table; having radial sector in fore wing partly black; differs from both in pronotal marks, and other points. Face yellowish, unmarked; palpi pale; antennae pale, no distinct stria on the basal joint, a large reddish, median, triangular mark on the vertex; pronotum with a reddish spot at each anterior corner, a large reddish, transverse mark on middle of each side, and the hind border narrowly reddish; eight reddish spots on mesoand metanotum forming two rows; abdomen with transverse reddish 
marks on several segments near the base; legs pale. Wings with green venation; in fore wings the gradates, many costals, origin of radial sector, and cross-vein to median, the divisory and bases of second, third, and some other cubital cells wholly black; radials in part, and origin of branches of the radial sector, and most of the marginal forks in part, black. In the hind wings the gradates, and part of marginal forks dark; stigma not distinct in either pair. Wings large and broad, hind wings acute at tip; gradates subparallel, inner (of seven or eight) scarcely nearer to the radial sector than to the outer (of six or eight), the veinlets not much disjointed; third cubital cell of moderate length, tip oblique; marginal forks over three times as long as broad; 20 costals before stigma in fore wing. Pronotum rather longer than broad, tapering in front.

Expanse $44 \mathrm{~mm}$.

\section{LeUCOCHRYSA Minima, sp. nov.}

Type-- M. C. Z. 10,061. Colombia: Caldras, 4,400 ft., May. H. S. Parish. Three specimens.

Pale yellowish; face, palpi, and antennae unmarked, no marks on pronotum or rest of thorax; wings with green venation; in fore wings the radial sector in part, the gradates, some of the costals, the radials in part, and sometimes parts of other veinlets, dark; in hind wings the gradates are dark; stigma dark green, in hind wings with brown spot at the base. Wings rather long, in hind pair acute at tip; gradates subparallel, five in inner, six in outer series, veinlets widely separated, the inner series much closer to the radial sector than to the outer series; marginal forks two and one half times as long as broad, 16 costals before stigma, divisory arising very near to cubitus, third cubital cell not very long, wide at tip. Pronotum much broader than long.

Expanse $26 \mathrm{~mm}$.

LEUCOCHRYSA CLEPSYDRA, sp. nov.

Type.-M. C. Z. 10,062. Colombia: Caldras, 4,400 ft., May. H. S. Parish; Inmbo, Cauca, 3,000 ft., January. A. H. Fassl. Four specimens.

Runs to $L$. azevedoi or stictocera in Navas table of South American species, having part of radial sector in both wings black, and a blackish margin to hind wings; it differs at once in the pale antennae, not 
marked with dark on the basal part. The face shows only a faint reddish streak on each cheek, the palpi pale, antennae pale, the basal joint with a superior reddish stria; pronotum with two reddish spots on each side margin. Wings with green venation, marked with black, in fore wings the gradates, and marginal forks black, and part of the costals, radials, and branches of radial sector dark at one or both ends, origin of radial sector black; in hind wings the gradates are not dark, the marginal forks partly dark, and the marginal vein black on outer portion; stigma in hind wings distinct, hardly so in the fore wings; both wings broad; seven or eight gradates in each series in each wing, the series nearly parallel, and the inner series rather nearer the radial sector than to the outer series; third cubital cell very long (in $L$. azevedo $i$ very short); about 25 costal cross-veins in fore wing before the stigma.

Expanse $40 \mathrm{~mm}$.

Chrysopa nimbosa, sp. nov.

Type.-M. C. Z. 10,063. Central Africa: Oubangui, Chari-Tchad, Bangui. E. Le Moult. Two specimens.

Close to C. conradtina Navas; the wings spotted as in that species, also the head and antennae so marked. In the wings the stigma is not so distinct, only black-bordered veins, and in the hind wings the stigmal band is more interrupted. In both wings the discal veins and those near middle of hind border are margined with pale yellowish brown; and in several cells so margined behind the stigma the central area is silvery white; the thorax has a broad black band across between the bases of both pairs of wings. Venation as in $C$. conradtina. The abdomen has the last two dorsal segments black, and a median black stripe on dorsum to middle of length.

\section{Chrysopa submarginata, sp. nov.}

Type--M. C. Z. 10,064. Peru: Lima, 12, 20 August. H. S. Parish. Two specimens.

Green or yellowish. Cheeks with red stripe from eyes to mouth; palpi marked with black, the antennae all pale, behind the eyes there is a red line to the pronotum, latter with a red stripe each side but remote from the side margin; anterior lobe of mesonotum with red spot each side; legs pale. Wings with green venation, many crossveins marked with black, the gradates, ends of costals and radials, 
several near base of wings, and some branches of rađial sector and cubitus black at origin. Wings long, acute, gradates very oblique, parallel, each of six veinlets, inner as near outer series as to the radial sector, marginal forks two and one half times as long as broad, about 20 costals before stigma, divisory ends beyond the cross-vein; in hind wings three inner and seven outer gradates, these black, other venation green, stigma in both pairs very long, deep green. Pronotum slender, about one and one half as long as broad, tapering in front.

Expanse $33 \mathrm{~mm}$.

Chrysopa hestia, sp. nov.

Type-- M. C. Z. 10,065. Argentina. E. LeMoult. One specimen.

Runs to $C h$. gonzalezi but differs in markings of wings, and more especially in the position of the inner gradate series, which is placed nearly transversely across the wings. Face yellowish, a faint reddish stripe on each cheek, last joint of palpi marked with dark, antennae pale, vertex green, thorax and abdomen deep green, pronotum with side margins red, and also the sides of thorax above base of wings; legs pale; wings with green venation, in fore wing the stigma dark at base and faint clouds along the outer four cross-veins between radius and radial sector, both gradate series and the last branch of the radial sector to median vein margined with pale brown; hind wings unmarked, except the stigma is a darker green. Wings are moderately slender, nearly acute at tips, the divisory ending before the cross-vein, the outer gradate series of six veinlets curved as to be nearly parallel to the outer margin, the inner series of five veinlets nearly transverse, none much disjointed; marginal forks fully three times as long as broad; about 16 costals before the stigma in fore wings; in hind wings the gradates, of five and six veinlets, are subparallel, and more oblique than in the fore wings. Pronotum a little longer than broad, narrowed in front.

Expanse $24 \mathrm{~mm}$.

\section{Myrmeleonidae.}

Dendroleon sumatranum, sp. nov.

Type.-M. C. Z. 10,066. Sumatra: Medan, Doloc Baros Estate, May. E. Le Moult. One specimen.

Face and vertex yellowish brown, latter only very indistinctly 
marked; antennae also yellowish brown, darker toward tip; pronotum brown, not marked, rest of thorax and abdomen pale yellowish brown; legs pale, tarsi dark, and tips of femora and tibiae also. Wings pale, with pale venation; several large dark rounded spots on each wing and on fore wing other smaller spots, but all are very faint (perhaps the specimen is teneral). In the hind wing are five large spots, three behind radius, one near base, one before middle and one just before stigma, another large one behind the latter and behind the median vein, and a large one at tip, partly broken by pale; along outer hind margin are three smaller dark spots. In fore wing the stigma is dark, and about four spots of medium size behind the radius, and four or five smaller spots, a number along the outer and hind margin, several along the cubitus and median veins, and one or two near tip. Antennae longer than the head and thorax together, not strongly clavate; pronotum but little longer than broad; legs very slender, the tibia a little longer than femur, the basal tarsal joint as long as the next three together, spurs as long as two joints. Wings broad at stigmal region, very filmy, and very densely veined; at least 75 costals before stigma in fore wing, all simple; radial sector with twelve branches; three cross-veins before radial sector in fore wing, one in the hind wing; about 18 or 20 cubitoanal cross-veins in fore wing; in hind wings the anal runs into the cubital fork; marginal venation extremely dense.

Expanse $76 \mathrm{~mm}$.

Glenoleon Conspersum, sp. nov.

Type--M. C. Z. 10,067. Queensland: Herbeton, 11 February. F. P. Dodd. One specimen.

Face yellowish; a large interantennal black mark from eye to eye, rather convex below, and straight across above; antennae dark, not banded; vertex brown, with four black spots in a transverse row, and in front two transverse lines; pronotum mostly black, a faint median line, two rounded submedian spots each side on front part, and two oblique sublateral spots on posterior part, all pale; a pale spot on median lobe each side, and pale streaks near and extending on the mésoscutellum; metanotum with a pale streak each side. Abdomen black, faint pale median marks on some of the segments. Femora black, tibiae of front and middle pairs banded with pale near base, before middle, and again toward tip; basal tarsal segment pale, rest, 
dark; hind tibia pale, dark at tip, hind tarsi marked as others. Wings hyaline, veins mostly black, many of them in the fore wings margined with dark, in apical part and behind very densely so; a large spot under stigma, an interrupted dark streak between subcosta and radius; the spots along cubitus rather larger than the others. In hind wing there is a broad stigmal band and a square costal spot beyond dark. The wings are rather broad at stigmal region, tip (Plate 2, fig. 22) acute; near stigma the radial sector bends up to radius as in other species; three cross-veins before radial sector in fore wing, one in hind wing, twelve or thirteen branches of radial sector, costals not forked except near the stigma, in cubito-anal area several of the crossveins are crossed. In general the venation is similar to $G$. radiale.

Expanse $68 \mathrm{~mm}$.

I had labeled this as doubtfully G. falsus, but Petersen's recent figure of that species shows this to be distinct in the heavily spotted fore wings, and the large spot beyond stigmal band in the hind wings.

\section{Panorpidae.}

Panorpa interrupta, sp. nov.

Type-M. C. Z. 10,068. N. Car:: Raleigh, late September. F. Sherman. Three specimens.

Pale yellowish; antennae (beyond basal joints) black; wings hyaline, a trifle flavescent toward base, marked with black much as in $P$. venosa and $P$. virginica. A fairly broad apical band, a narrow stigmal band, broadly interrupted near middle, two subbasal and a basal spot, and a few other smaller marks; veins mostly dark; the subcosta and most of the radius flavescent; subcosta reaching to the stigma. Male abdomen and genitalia very similar to $P$. virginica; the horn on fifth segment slender, curved and remote from tip as in that species. The uncus is longer than in P.rufescens; the harpe is not so long as in $P$. virginica; the clasper has on the upper side a ridge with an apical fringe of hair curving over the uncus; this ridge is similar to but much smaller than in $P$. virginica.

Expanse $22 \mathrm{~mm}$.

In appearance similar to $P$. rufescens, but in genital structure related to $P$. virginica; the broken stigmal band separates it from $P$. virginica. 


\section{LIMNEPHILIDAE.}

LimNePHILUS SANSONI, sp. nov.

Type.-M. C. Z. 10,069. Alberta: Banff. N. B. Sanson. Three specimens.

Group of $L$. combinatus, but more heavily marked with dark. Yellowish, with gray or yellowish hairs; abdomen black, venter paler; front tibiae with mostly yellow spines. Wings yellowish; fore wings heavily marked with brown behind and on the outer part, and a very dark spot at stigma; the two oblique spots on middle across cubitus are very distinct, a large clear spot in base of apical and first subapical cells, and another over apical parts of fifth apical and first and second subapical cells; a dark streak along the second anal vein. All the dark brown is broken by rounded hyaline spots. Venation as in $L$. combinatus, but the fore wings not as elongate. The superior appendages of female are similar to those of $L$. combinatus, but the intermediate ones are shorter than in that species, and more acuminate. In the male the superior appendages seen from the side slope more behind, and the lower inner edge not armed with such large teeth as in L. combinatus; the intermediate superior appendages are much larger than in $L$. combinatus. From L. oslari the female differs in the much longer superior appendages, and in the male the superior appendages are nearly the same shape, but in $L$. oslari they are very heavily armed with teeth on the inner surface toward tip, while here they are scarcely armed at all; in $L$. oslari the intermediate superior appendages are smaller and with slightly curved tips. (Plate 1, fig. 8).

Expanse $34 \mathrm{~mm}$.

Most of the specimens seen appear much like normal $L$. externus, but not closely related to that species.

\section{LIMNEPHILUS ROTUNDATUS, sp. nov.}

Type--M. C. Z. 10,070. Calif.: Lake Tahoe. W. K. Fisher. One specimen.

In general marked as in L. gravidus Hagen, the tibiae and tarsi being banded with dark; the fore wings rather more heavily marked than the normal $L$. gravidus, but on the same plan; the oblique pale spots across the cubitus being distinct; the outer margin of fore wing nearly truncate. Venation like that of $L$. gravidus. The female differs at once from $L$. gravidus, $L$. vastus, and $L$. intermedius in having 
the inferior appendages short and rounded (instead of triangular); the superior appendages are about as stout as in L. intermedius, with the tip slightly pointed and turned upward (Plate 1, fig. 14).

Expanse $42 \mathrm{~mm}$.

\section{LIMNEPHILUS INTERMEDIUS, sp. nov.}

Type-- M. C. Z. 10,071. Wash.: Olympia. T. Kincaid. One specimen.

In general similar to L. gravidus Hagen the tibiae and tarsi banded with dark. The fore wings are rather more evenly marked with dark, a heavy dark band over the anastomosis; shape of wings and venation as in that species, the outer margin being a little convex, and the fourth apical cell in both wings being nearly as broad at base as the third. The female differs from $L$. gravidus in the genitalia, (cf. Plate 1, fig. 11, 12) the superior appendages being much broader and heavier, but less acuminate than in L. vastus (Plate 1, fig. 13).

Expanse $46 \mathrm{~mm}$.

\section{Limnephilus flavastellus, sp. nov.}

Type-- M. C. Z. 10,072. British Columbia: Wellington. T. Bryant and D. Jones. Two specimens.

Yellowish, with whitish or golden hair, leg I blackish on anterior side of femur and posterior side of the basal tarsal joints; the hind tibiae rather brownish, spines black, a few on front tibiae near base may be yellowish. Fore wings yellowish, darker yellowish brown on posterior half and on outer part; a large hyaline spot beyond anastomosis, and a curved hyaline streak above the median vein and curving back to cubitus, the brown by the hyaline streak is darker than elsewhere and sharply limited, hind wings hyaline, all veins yellowish. Shape of wings and venation like $L$. sitchensis, except that the fourth apical cell in both wings is not so much narrowed at base. In the male the lower appendages have a lobe near tip. Genitalia (Plate 1, fig. 16, 17).

Expanse $33 \mathrm{~mm}$.

Hesperophylax magnus, sp. nov.

Type.-M. C. Z. 10,075. Ariz.: Palmerlee, Cochise Co. C. R. Bièderman; Calif.: Santa Ana River, San Bernardino Mts., 30 July, 
J. Grinnell; Fish Creek, San Bernardino Mts., 20 June. J. Grinnell; Tanquitz Valley, 19 July. F. Grinnell; N. Mex.: Ft. Wingate, 21 Aug. J. Woodgate; Utah: Stockton, 22 July. T. Spaulding; Colo.: South Park, 20 Aug., E. J. Oslar. Nine specimens.

Colored and marked as in $H$. occidentalis, but the apical part of the silvery stripe has the sides more nearly parallel, not narrowed at tip, and this stripe is more strongly margined than usual in $H$. occidentalis. All the specimens are larger than $H$. occidentalis. It is at once separated in that the superior appendages of the male are excised on outer edge, with the lower part prolonged; and in the female by having the superior appendages much broader and broadly rounded at tip (cf. Plate 1, fig. 9, 15).

Expanse 45 to $50 \mathrm{~mm}$.

\section{RHYACOPHILIDAE.}

Rhyacophila alberta, sp. nov.

Typc-M. C. Z. 10,073. Alberta: Banff, 27 September. N. B. Sanson. One specimen.

$\sigma^{7}$ Brown, clothed with black hair on face, yellowish on vertex and pronotum, tufts of black hair at base of wings; antennae brown, narrowly yellow at tips of the joints; abdomen beneath and genitalia yellowish. Legs yellowish, front and mid tibiae dark on basal half, very pale beyond, front and mid tarsi brown. Wings gray, fore wings rather densely marked with blackish spots and streaks, and with many pale, mostly rounded spots, some along margin; hind wings with tips of some apical veins darker. Maxillary palpi with second joint extremely long and slender; abdomen with long, sparse, fine, erect, white hairs on upper surface, as long as width of abdomen. Fore wings rather elongate; fork 2 reaches before fork 1 , fork 4 as long as its pedicel; genitalia similar to $R$. bipartita, but there is only a minute rounded superior piece visible, and the internal parts are different (Plate 1, fig. 10).

Expanse $21 \mathrm{~mm}$.

HydropsychidaE.

Arctopsyche phryganoides, sp. nov.

Type-- M. C. Z. 10,074. Alberta: Banff. N. B. Sanson. One specimen.

Face pale, with black hair, front and vertex black, with yellowish 
hair; palpi pale, antennae pale, tips of joints dark; thorax pale through the middle, dark on sides, pleura pale; abdomen blackish, venter pale; legs pale. Wings longer and more slender than usual; fore wings densely irrorate with dark gray, becoming blackish on the larger spots and on the veins; the larger spots are over the anastomosis, and along the cubital and anal veins. The venation about as in $A$. grandis, but the cells narrower, and especially the apical cells, the outer margin is thus more oblique. The hind wings brownish, nearly uniform, but with a few pale spots on outer costal border; venation as in A. grandis, but the pedicel of fork 3 has a spurious vein (really fold) obliquely to the base of fork 2 .

Expanse $38 \mathrm{~mm}$.

Known at once by elongate, heavily irrorate fore wings; probably referred to by McLachlain, Monog. Revis., p. 379, in a footnote. 
EXPLANATION OF THE PLATES. 


\section{PLATE 1.}

Fig. 1. Psocus bilobatus, tip of male abdomen.

Fig. 2. Taeniopteryx parvula, venter.

Fig. 3. Taeniopteryx parvula, side of $\sigma^{x}$ genitalia.

Fig. 4. Taeniopteryx nigripennis, venter $\&$ above, $\sigma^{7}$ below.

Fig. 5. Campsurus parishi, $\sigma^{7}$ genitalia.

Fig. 6. Taeniopteryx grinnelli, $\sigma^{7}$ genitalia.

Fig. 7. Taenioptery $x$ pallida, $q$ venter.

Fig. 8. Limnephilus sansoni $q$ genitalia above, $\sigma^{7}$ from side and inner surface superior appendage of $\sigma^{x}$.

Fig. 9. Hesperophylax magnus, $\sigma^{7} \circ$ genitalia.

Fig. 10. Rhyacophila alberta, $\sigma^{\pi}$ genitalia from below and from side.

Fig. 11. Limnephilus intermedius, $\odot$ genitalia.

Fig. 12. Limnephilus gravidus, $q$ genitalia. .

Fig. 13. Limnephilus vastus, $\circ$ genitalia.

Fig. 14. Limnephilus rotundatus, $\&$ genitalia.

Fig. 15. Hesperophylax occidentalis, $\sigma^{7} \&$ genitalia.

Fig. 16. Limnephilus flavastellus, $\odot$ genitalia from above.

Fig. 17. Limnephilus flavastellus, $o^{7}$ genitalia from side. 


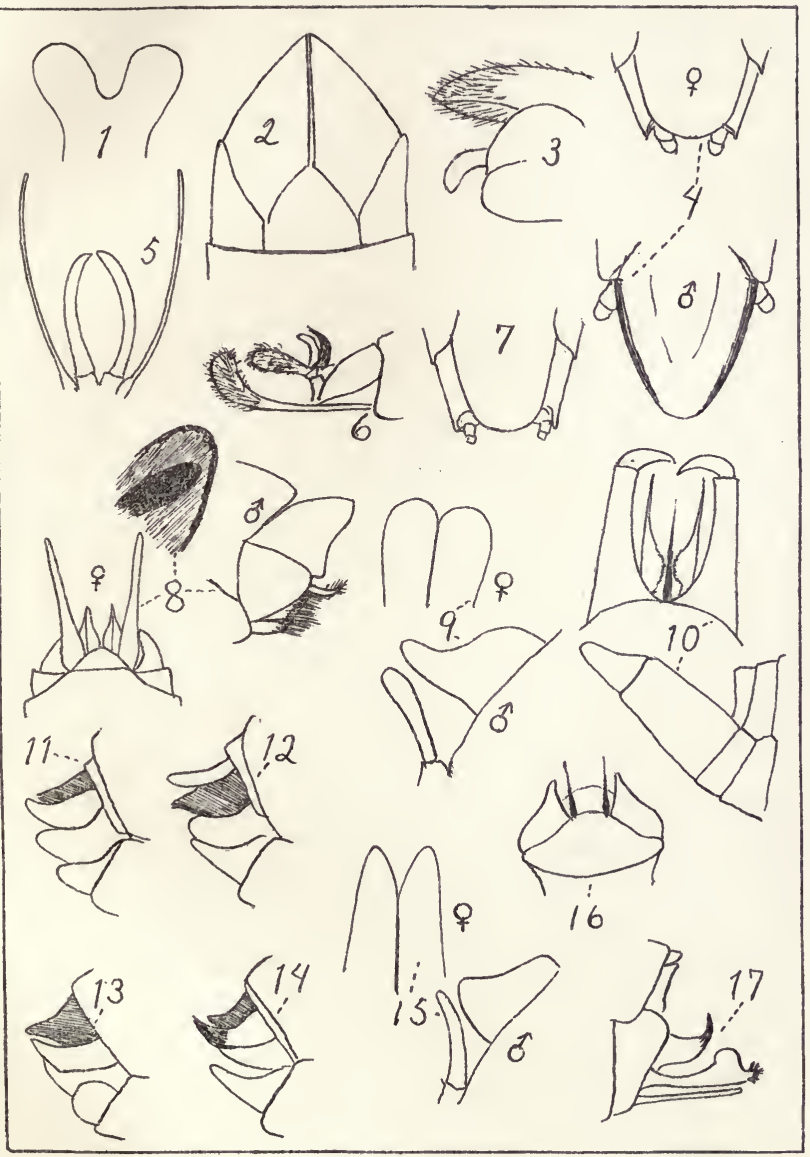



PLATE 2. 


\section{PLATE 2.}

Fig. 18. Perla innota, ventral plate, . Fig. 19. Hemipsocus selysi, wings.

Fig. 20. Thraulus trijuncta, seta.

Fig. 21. Notiobiella costalis, genitalia, $\sigma^{7}$.

Fig. 22. Glenoleon conspersum, tip hind wing.

Fig. 23. Taeniostigma perkinsi, wings.

Fig. 24. Amphigerontia formosa, fore wing.

Fig. 25. Perla titusi, ventral plate, $\$$.

Fig. 26. Arsapnia bakeri, fore wing. 


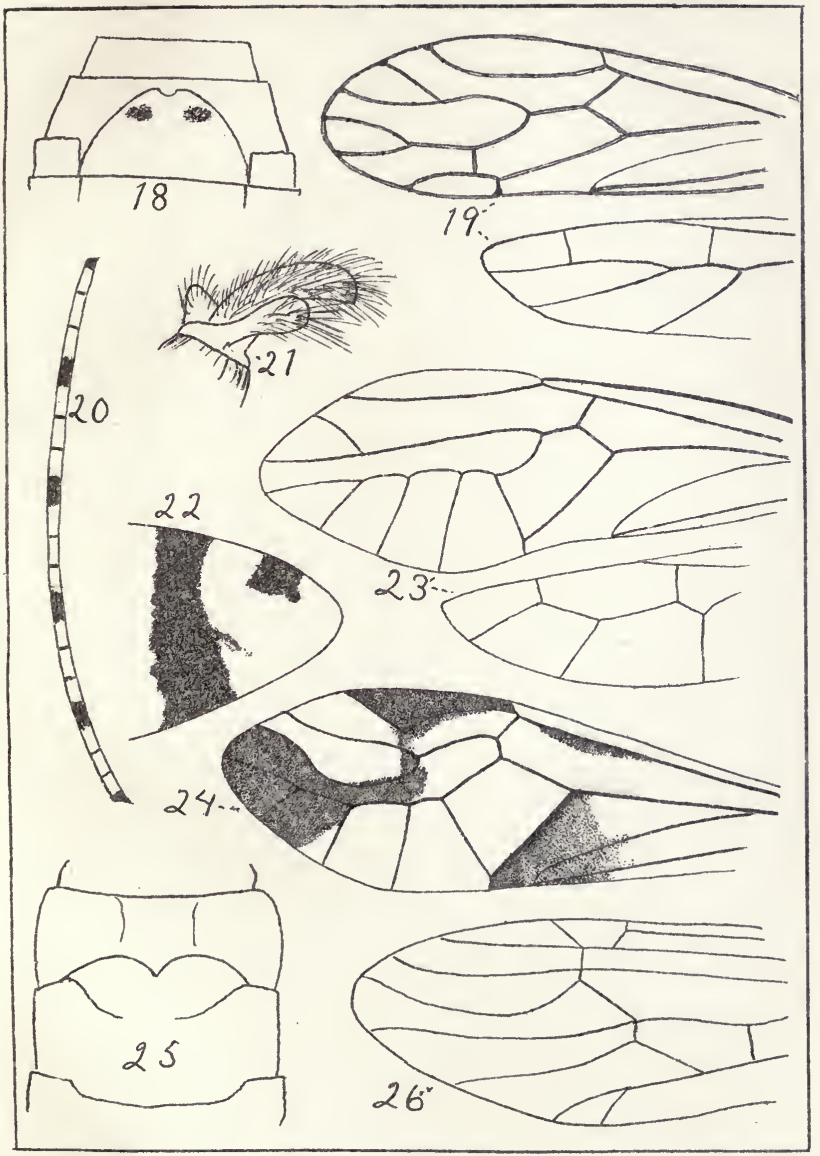




$$
\begin{gathered}
D 15242 \\
5-12
\end{gathered}
$$





\section{DATE DUE}

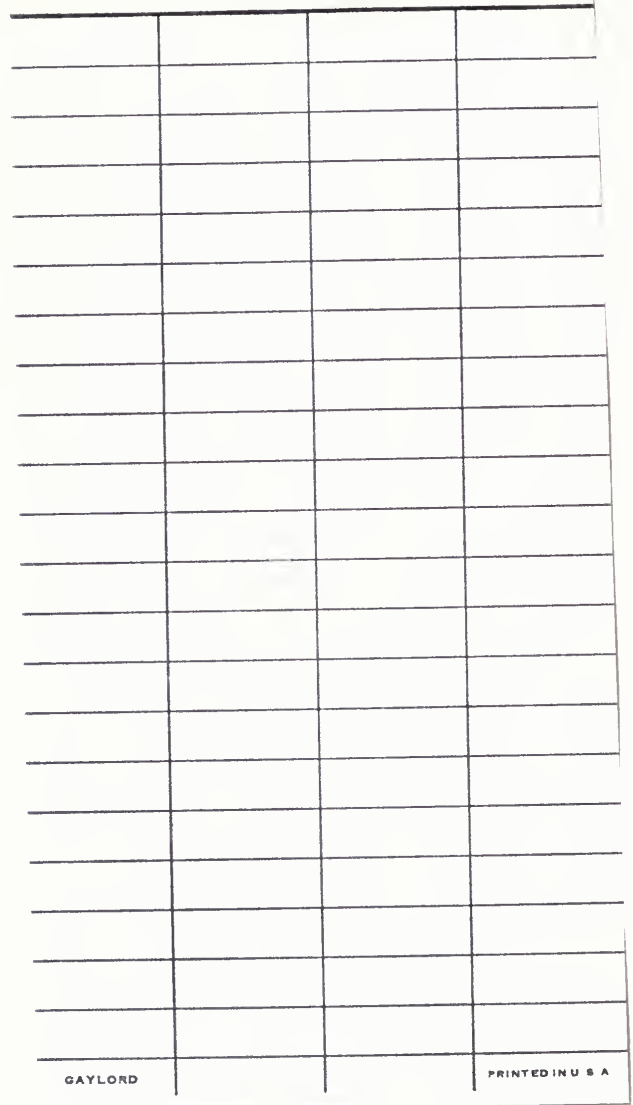


UC SOUTHERN REGIONAL LIBRARY FACIITY

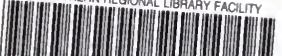

A 000857693

6 


\title{
MUSEUM OF COMPARATIVE ZOÖLOGY
}

\author{
AT HARVARD COLLEGE.
}

There have been published of the BuLLETiN Vols. I. to LIV., LVI., and Vols. LVIII. to LXI.; of the Merorrs, Vols. I. to XXXIV., and also Vols. XXXVI. to XXXVIII., XL. to XLII., XLIV., and XLVI.

Vols. LV., LVII., LXII. and LXIII. of the BuLletin, and Vols. XXXV., XXXIX., XLIII., XLV., XLVII to XLIX. of the MemoIrs, are now in course of publication.

The Bulletrin and MeMorRs are devoted to the publication of original work by the Officers of the Museum, of investigations carried on by students and others in the different Laboratories of Natural History, and of work by specialists based upon the Museum Collections and Explorations.

The following publications are in preparation:-

Reports on the Results of Dredging Operations from 1877 to 1880 , in charge of Alexander Agassiz, by the U. S. Coast Survey Steamer "Blake," Lieut. Commander C. D. Sigsbee, U. S. N., and Commander J. R. Bartlett, U. S. N., Commanding.

Reports on the Results of the Expedition of 1891 of the U.S. Fish Commission Steamer "Albatross," Lieut. Commander Z. L. Tanner, U. S. N., Commanding, in charge of Alexander Agassiz.

Reports on the Scientific Results of the Expedition to the Tropical Pacific, in charge of Alexander Agassiz, on the U. S. Fish Commission Steamer "Albatross," from August, 1899, to March, 1900, Commander Jefferson F. Moser, U. S. N., Commanding.

Reports on the Scientific Results of the Expedition to the Eastern Tropical Pacific, in charge of Alexander Agassiz, on the U. S. Fish Commission Steamer "Albatross," from October, 1904, to April, 1905, Lieut. Commander L. M. Garrett, U. S. N., Commanding.

Contributions from the Zoölogical Laboratory, Professor E. L. Mark, Director. Contributions from the Geological Laboratory, Professor R. A. Daly, in charge.

These publications are issued in numbers at irregular intervals. Each number of the Bulletin and of the Memoirs is sold separately. A price list of the publications of the Museum will be sent on application to the Director of the Museum of Comparative Zoölogy, Cambridge, Mass. 